\title{
PREPARATION AND CHARACTERIZATION OF LAFUTIDINE AS IMMEDIATE RELEASE ORAL STRIP USING DIFFERENT TYPE OF WATER-SOLUBLE POLYMER
}

\author{
SABA ABDULHADI JABIR, HALAH TALAL SULAIMAN
}

Department of Pharmaceutics, College of Pharmacy, University of Baghdad, Baghdad, Iraq

Email: sabahadee77@yahoo.com

Received: 14 Jul 2018, Revised and Accepted: 11 Aug 2018

\begin{abstract}
Objective: The objective of the present study was to design and optimize oral fast dissolving film (OFDF) of practically insoluble drug lafutidine in order to enhance bioavailability and patient compliance especially for a geriatric and unconscious patient who are suffering from difficulty in swallowing.

Methods: The films were prepared by a solvent casting method using low-grade hydroxyl propyl methyl cellulose (HPMC E5), polyvinyl alcohol (PVA), and sodium carboxymethyl cellulose (SCMC) as film forming polymers. Polyethylene glycol 400 (PEG400), propylene glycol (PG) and glycerin were used as a plasticizer to enhance the film forming properties of the polymer. Tween 80 ( $1 \%$ solution) and poloxamer407 were used as a surfactant, citric acid as a saliva stimulating agent, and croscarmellose as a super disintegrant. Films were then tested for both physical (weight variation, thickness, surface $\mathrm{pH}$, drug content) and mechanical (folding endurance, tensile strength, percent elongation, Young's modulus) characteristics. In vitro disintegration, time and drug release profile were also determined for each formula.
\end{abstract}

Results: Films were found to be satisfactory when evaluated for both physical and mechanical characterizations. The surface pH of all the films was found to be within the range of salivary $\mathrm{pH}$ 6.8. The USP dissolution apparatus type II (paddle type) was used for in vitro drug release studies. The optimized formulation $\mathrm{F} 13$ gave $100 \%$ of drug released at $2 \mathrm{~min}$. It also showed satisfactory surface pH (6.2 \pm 0.2$)$, drug content (100.1 $\pm 0.01 \%)$, the disintegration time of $(7.0 \pm 0.5)$ seconds and the time needed for $80 \%$ of medication to be released (T80\%) was $0.96 \mathrm{~min}$.

Conclusion: Lafutidine OFDF was formulated using HPMC E5 as film-forming a polymer with PEG400 as a plasticizer. Combination of tween80 (1\% solution) and poloxamer407 as a surfactant were used in the presence of croscarmellose as a super disintegrant. The chosen OFDF disintegrates within seven seconds, releases the drug rapidly and gives an action.

Keywords: Lafutidine, Oral fast dissolving film, OFDF, Solvent casting method

(C) 2018 The Authors. Published by Innovare Academic Sciences Pvt Ltd. This is an open access article under the CC BY license (http://creativecommons.org/licenses/by/4.0/) DOI: http://dx.doi.org/10.22159/ijap.2018v10i5.28292

\section{INTRODUCTION}

Oral administration is one of the most crucial routes of administering a drug with high credit to obtain a systemic effect due to its simplicity, comfort ability by producing no pain compared with the systemic administration. However, disadvantages in case of certain oral dosage forms capsules and tablets, such as swallowing problems especially for children, infants and elderly leading to in compliance and disadherence to the treatment [1]. Approximately $35 \%$ of the population showed dysphagia and troubles with swallowing also people with hiccups, gagging, sea/motion sickness, and obstruction of the esophagus pathway will be forced to search for other alternatives which favor the systemic drug delivery such as fast-dissolving medication [2].

Oral fast dissolving films (OFDFs) are the most advanced form of an oral solid dosage form, which disintegrate or dissolve within a minute when placed in the mouth without drinking water or chewing. The anatomical composition of the buccal cavity, high blood flow as well as the high permeable nature of the buccal mucosa make using of such dosage forms have quite privileges such as rapid onset, with immediate bioavailability [3].

Oral films are formulated using polymers, plasticizer, flavors, colors, and sweeteners. Hydrophilic polymers are rapidly disintegrated or dissolved in the oral cavity delivering the drug to the systemic circulation that was used in the preparation of OFDFs. Plasticizer helps to enhance the flexibility and reduces the brittleness of the strip [4].

Lafutidine is a new H2-receptor antagonist, after absorption in the small intestine, it reaches gastric cell by the systemic circulation, then directly and quickly binds to gastric cell H2-receptor resulting in promote inhibition of gastric acid secretion. The drug is predominantly metabolized in the liver by microsomal enzyme CYP3A4 and CYP2D6. Its major metabolites are hydroxylated lafutidine and sulfonyl lafutidine $[5,6]$. Its maximum plasma concentration of $133.9 \pm 8.1(\mathrm{ng} / \mathrm{ml})$ will be reached at time of (1.844 \pm 0.334$) \mathrm{h}$ [7]. It has a biological half-life of $1.92 \mathrm{~h}$ [8].

Lafutidine has a receptor binding affinity which is 2-80 times higher than other representative $\mathrm{H} 2$-receptor antagonists (e. g. famotidine, ranitidine and cimetidine) [9].

Lafutidine exerts gastroprotective effects independent of its antisecretory action by increasing intracellular Ca 2+ion concentration in endothelial cell that provokes the release of neurotransmitters CGRP which stimulate nitric oxide(NO) production in endothelial cell,where NO plays a role in the control of gastric mucosal blood flow by vasodilatation within the gastric microvasculature [10].

Lafutidine has been found to significantly increase plasma somatostatin level at (0.3-2) $\mathrm{h}$ after administration where somatostatin inhibites gastric acid secretion by acting directly on its receptor on a parietal cell and indirectly by decreasing gastrin from antral G cell [9].

The aim of this study was to formulate and in vitro evaluate an OFDF of practically insoluble lafutidine to enhance it's solubility, improve compliance and bioavailability as well as to produce an immediate release action of lafutidine from the film for an efficient management of gastric ulcers,duodenal ulcers and gastric mucosal lesions combined with acute or chronic gastritis.

\section{MATERIALS AND METHODS}

\section{Material}

Lafutidine and Poloxamer 407 were purchased from Hangzhou Hyper Chemicals Limited, Zhejiang; China. HPMC E5, PVA, and SCMC were supplied from Samarra Drug Industry (SDI) as a gift. Glycerin and PEG400 were purchased from Fluka Chemical AG, Switzerland. PG was purchased from Evans Medical Ltd, Liverpool, England. All 
other chemicals and solvents were of analytical reagent grade, and deionized water also was used in this study.

\section{Method}

\section{Construction of calibration curve}

Calibration curve for lafutidine in phosphate buffers ( $\mathrm{pH}$ 6.8) were made by preparing serial dilutions of the drug from a stock solution $(0.48 \mathrm{mg} / \mathrm{ml})$. Samples $(9.6,19.2,38.4,48,57.6$ and $76.8 \mu \mathrm{g} / \mathrm{ml})$ were then analyzed spectrophotometrically for lafutidine at its $\lambda$ max $(273 \mathrm{~nm})$ [11].

\section{Method for preparation of lafutidine OFDF}

Fourteen formulas were prepared (F1-F14) as listed in table 1 by using the solvent casting method; every film of about $4 \mathrm{~cm}^{2}$ area must contain $10 \mathrm{mg}$ of lafutidine. The size and number of films that formulated for every group designed as the following:

The dose of the drug to be incorporated in each $4 \mathrm{~cm}^{2}$ film $=10 \mathrm{mg}$ of lafutidine.

The diameter of petri dish is $11 \mathrm{~cm}$, so that the radius $=5.5 \mathrm{~cm}$.

Area of Petri dish $=\pi \mathrm{r}^{2}, 3.14 \times(5.5 \mathrm{~cm})^{2}=94.985 \mathrm{~cm}^{2}$ approximately $95 \mathrm{~cm}^{2}$.
A number of $4 \mathrm{~cm}^{2}$ films obtained from the main film $=95 \mathrm{~cm}^{2} \div 4$ $\mathrm{cm}^{2}=23.75$ films approximately 24 films each with area $4 \mathrm{~cm}^{2}$.

The amount of lafutidine should be incorporated in the area considered is calculated as follow:

24 film $\times 10 \mathrm{mg}=240 \mathrm{mg}$.

The OFDFs of lafutidine were prepared by a solvent casting method. The considered quantity of film-forming polymer was dissolved in $20 \mathrm{ml}$ of solvent (distilled water) with constant stirring using a magnetic stirrer for two $\mathrm{h}$ to form a homogenous polymeric solution. To this polymeric solution, a suitable amount of plasticizer was added with continuous stirring for another one $\mathrm{h}$. In another beaker, the drug was dissolved in $8 \mathrm{ml}$ mixture of $(0.1 \mathrm{~N} \mathrm{HCL}$ and $1 \%$ tween80 solution) to form a clear solution; then the volume was completed to $10 \mathrm{ml}$ with distilled water. Saliva stimulating agent, sweetener and superdisintegrant were added to the drug solution. The two solutions (polymer and drug) were mixed using a magnetic stirrer for one $h$; then it was kept in a sonicator for degassing. The bubble-free solution was cast on to a petri dish with a diameter of 11 $\mathrm{cm}^{2}$ and kept in hot air oven $\left(60^{\circ} \mathrm{C}\right)$ overnight. The dried film was then removed and cut into the desired shape and size $(2 \mathrm{~cm} \times 2 \mathrm{~cm})$ for the intended application. Cuts or defectiveness were omitted from the study [12].

Table 1: Composition of lafutidine oral films formulas

\begin{tabular}{|c|c|c|c|c|c|c|c|c|c|c|c|c|c|c|}
\hline Ingredients present in each film (mg) & F1 & F2 & F3 & F4 & F5 & F6 & F7 & F8 & F9 & F10 & F11 & F12 & F13 & F14 \\
\hline Lafutidine & 10 & 10 & 10 & 10 & 10 & 10 & 10 & 10 & 10 & 10 & 10 & 10 & 10 & 10 \\
\hline HPMC E5 & 25 & & & 25 & 25 & 25 & 25 & 25 & 25 & 25 & 25 & 25 & 25 & 25 \\
\hline PVA & & 25 & & 25 & 12.5 & & & & & & & & & \\
\hline SCMC & & & 25 & & & 12.5 & & & & & & & & \\
\hline PEG 400 & 7.5 & 7.5 & 7.5 & 7.5 & 7.5 & 7.5 & 8.5 & 6 & 4 & & & 7.5 & 7.5 & 7.5 \\
\hline Glycerin & & & & & & & & & & 7.5 & & & & \\
\hline PG & & & & & & & & & & & 7.5 & & & \\
\hline Tween 80 & 1.6 & 1.6 & 1.6 & 1.6 & 1.6 & 1.6 & 1.6 & 1.6 & 1.6 & 1.6 & 1.6 & & 1.6 & 1.6 \\
\hline Poloxamer407 & & & & & & & & & & & & 1.6 & 1.6 & 1.6 \\
\hline Croscarmellose & 1.5 & 1.5 & 1.5 & 1.5 & 1.5 & 1.5 & 1.5 & 1.5 & 1.5 & 1.5 & 1.5 & 1.5 & 1.5 & \\
\hline Citric acid & 1.5 & 1.5 & 1.5 & 1.5 & 1.5 & 1.5 & 1.5 & 1.5 & 1.5 & 1.5 & 1.5 & 1.5 & 1.5 & 1.5 \\
\hline Vanilla & 1.5 & 1.5 & 1.5 & 1.5 & 1.5 & 1.5 & 1.5 & 1.5 & 1.5 & 1.5 & 1.5 & 1.5 & 1.5 & 1.5 \\
\hline Sodium saccharin & 1.5 & 1.5 & 1.5 & 1.5 & 1.5 & 1.5 & 1.5 & 1.5 & 1.5 & 1.5 & 1.5 & 1.5 & 1.5 & 1.5 \\
\hline
\end{tabular}

\section{Evaluation of lafutidine OFDF}

\section{Physical characterization of the prepared films}

Physical characteristics such as color, thickness, brittleness, peeling ability, transparency, surface smoothness, tack property and filmforming capacity can be carried out by visual inspection for all the above characteristics [13].

\section{Weight variation}

The uniformity of the film formed was confirmed by weight variation test. Ten randomly selected films from each patch (each of $2 \mathrm{~cm} \times 2 \mathrm{~cm}$ ) were weighed individually and matched with the mean weight for deviation [14].

\section{Thickness measurements}

Digimatic and Vernier Caliper was used to measure the film thicknesses. Each film was measured at five positions (central and the four corners) the mean thickness was calculated. This test was performed on six films of each formulation and mean $\pm S$. D calculated [15].

\section{Drug content uniformity}

Drug content was determined by taking three films from each formulation patch randomly and weighed individually. Each film was dissolved in $5 \mathrm{ml}$ of methanol, sonication; the volume was completed to $10 \mathrm{ml}$ with distilled water then filtered through $0.45 \mu \mathrm{m}$ filter syring. Using $100 \mathrm{ml}$ volumetric flask, $1 \mathrm{ml}$ of the filtrate was diluted with distilled water to the mark and analyzed spectrophotometrically at $\lambda \max (279 \mathrm{~nm})$. The average drug content was calculated [16].

\section{Determination of surface $\mathrm{pH}$}

Surface $\mathrm{pH}$ determination is important to investigate any side effects when using the OFDFs in vivo, due to the irritation of the mucosal membrane of an oral cavity by acidic or basic pH. OFDF's pH value was measured by dissolving one film in $2 \mathrm{ml}$ of distilled water and the solution's $\mathrm{pH}$ was determined using Schott Gerate $\mathrm{pH}$-meter.

Different $\mathrm{pH}$ value will be expected because of the fact of using a different film forming polymers in the formulation of OFDFs along with the drug [17].

\section{Folding endurance}

The number of time the film is folded without breaking is known as the folding endurance value. Folding endurance is measured by manual repeated folding of the film at the same place till it broke. A film of an area of $4 \mathrm{~cm}^{2}$ was subjected to folding endurance by folding the film at the same place several times repeatedly until a visible crack was observed and the average values were calculated and reported. The value of folding endurance of more than 300 indicating that the formulation is good, tough and flexible [18].

\section{Tensile strength}

Define as the maximum value of forces applied on the film to breaks down. Tensometer was used to measure the tensile strength by holding a film of $5 \mathrm{~cm} \times 2 \mathrm{~cm}$ (which must be pure from air bubbles or any physical defectiveness and cut as dumbbell-shaped) longitudinally in it, then it was drawn at a level of $10 \mathrm{~mm} / \mathrm{min}$. Mathematically measurement of the tensile strength by dividing the applied force at which the film was broken on the cross-section area 
of it, as shown in the following equation. Mega Pascal (MPa) is a unit of tensile strength [19].

Tensile Strength $=$ Load to Break/Width $\times$ Thickness $\times 100$

\section{Percentage elongation}

The deformation of the film divided by the original dimension of it known as a strain which is referred to the stretches of the sample when stress is applied. Elongation related to the stretching of the film sample when stress is applied. As the plasticizer concentration increases the elongation of the film increases too. Percentage elongation $(\% \mathrm{E})$ was calculated by measuring the increase in the length of the film after tensile strength measurement by using the following formula [20].

Percentage Elongation $(\% \mathrm{E})=[$ Final length-Initial length $] \mathrm{X}$ $100 /$ Initial length

\section{Young's modulus}

Measuring the stiffness of the film is referred to young's modulus or elastic modulus. It is represented as the ratio of applied stress over strain in the region of elastic deformation as follows:

Young's modulus $=$ Slope X 100/Strip thickness X Cross-head speed

Hard and brittle film demonstrates high tensile strength and Young's modulus with small elongation [21].

\section{Percent moisture absorb (PMA)}

The physical stability of the film at high humid conditions was determined by this test. In the present study, the moisture absorption capacity of the lafutidine OFDFs was determined by keeping the preweighed films in the desiccator containing a saturated solution of potassium chloride, which maintains $79.5 \%$ relative humidity at room temperature for $72 \mathrm{~h}$. Average percentage moisture absorption of three films can be calculated by the following equation [22]:

$$
\% \text { Moisture absorption }=\frac{\text { Final weight }- \text { Initial weight }}{\text { Initial weight }} \times 100
$$

\section{In vitro disintegration time (DT)}

The time at which the OFDF starts to break down or disintegrate is known as the DT. It was measured by a petri dish method. The test was done by taking three films from each formula then in a petri dish $2 \mathrm{ml}$ of distilled water was adding for each film, it was shaken continuously, then measure the time at which the OFDF starts to break down or disintegrate. It was done in triplicate for all the formulations [23].

\section{In vitro dissolution study}

The dissolution study was carried out using USP type II (paddle apparatus) with $200 \mathrm{ml}$ of phosphate buffer $\mathrm{pH} 6.8$ as a dissolution medium maintained at $37 \pm 0.5^{\circ} \mathrm{C}$. The medium was stirred at $50 \mathrm{rpm}$ for a period of $20 \mathrm{~min}$. Samples were withdrawn by using a syringe fitted with a microfilter $(0.45 \mu \mathrm{m})$ at regular intervals $(1,2,3,4,5$, 10,15 and $20 \mathrm{~min}$ ) replaced with fresh medium in order to maintain sink conditions. Samples were analyzed spectrophotometrically at $273 \mathrm{~nm}$ for the drug content. Cumulative percent of lafutidine released was calculated and plotted against time [24].

\section{Statistical analysis}

The results of the experiments are given as a mean of triplicate samples \pm standard deviation and were analyzed according to the one way analysis of variance $($ ANOVA) at the level of $(\mathrm{P}<0.05)$ to determine if the changes in the applied factors are statistically significant at level of ( $\mathrm{P}$ $\leq 0.05)$ and non-significant at level of ( $p>0.05)$.

\section{RESULTS AND DISCUSSION}

\section{Visual inspection}

All the prepared OFDFs which contain HPMC E5, PVA, and SCMC showed homogenous and smooth surface properties, where as HPMC and PVA films were transparent, colorless, thin and soft while those prepared from SCMC were thin, soft, colorless and semi-transparent.

\section{Weight variation}

The average weights for all the prepared formulations were uniform and fit to the referred values as shown in table 2, so the strategy utilized for the preparation of films is reproducible and give films of uniform weight. Digital balance was used to determine the weight of the films, all show consistency.

\section{Thickness}

The average thickness values of films for all formulas were shown in table 2 . The thickness was found to vary between $(0.08 \pm 0.02)$ to $(0.16 \pm 0.01) \mathrm{mm}$. A very low standard deviation value is indicating that the method used for the formulation is reproducible and give films of uniform thickness, hence dosage accuracy in each film can be ensured.

\section{Drug content}

The formulated lafutidine films showed an acceptable quantity of medicament ranged from $(96.8 \pm 0.4 \%)$ to $(102.2 \pm 0.2 \%)$ as shown in table 2 . The accepted range of content uniformity labeled in BP is ranged from $85 \%$ to $115 \%$. The results is obeying this range, which indicating that the solvent casting method used in preparing of lafutidine OFDFs is very efficient. So the drug was spread uniformly throughout the $4 \mathrm{~cm}^{2}$ constant area of the films.

\section{Surface $\mathrm{pH}$ measurement}

All the prepared films showed an acceptable surface $\mathrm{pH}$ value $(6.1 \pm 0.2)$ to $(6.5 \pm 0.1)$ as viewed in table 2 when compared to the $\mathrm{pH}$ of oral mucosa indicating that it does not cause an irritation to it.

\section{Percent moisture absorb (PMA)}

Moisture uptake holds a critical investigation on drug stability. All the reported values of moisture uptake are listed in the table 2 . It was detected that all the polymers were hydrophilic in nature and the moisture absorb values ranged from $(1.0 \pm 0.6 \%)$ to $(9.4 \pm 0.1 \%)$.

Table 2: Physical evaluation parameters of lafutidine OFDFs formulas

\begin{tabular}{|c|c|c|c|c|c|c|}
\hline Formula code & $\begin{array}{l}\text { Weight } \\
\text { variation }(\mathrm{mg}) * * *\end{array}$ & Thickness (mm) ${ }^{* *}$ & $\begin{array}{l}\text { Drug } \\
\text { content* }\end{array}$ & $\begin{array}{l}\text { Surface } \\
\text { PH* }^{*}\end{array}$ & $\begin{array}{l}\text { In vitro } \\
\text { DT(s) * }\end{array}$ & PMA* \\
\hline F1 & $52.64 \pm 0.01$ & $0.08 \pm 0.02$ & $100.1 \pm 0.1$ & $6.3 \pm 0.5$ & $8 \pm 0.5$ & $3.8 \pm 0.55$ \\
\hline $\mathrm{F} 2$ & $52.93 \pm 0.1$ & $0.11 \pm 0.01$ & $99.6 \pm 0.2$ & $6.2 \pm 0.3$ & $10 \pm 0.2$ & $4.0 \pm 0.6$ \\
\hline F3 & $52.11 \pm 0.2$ & $0.1 \pm 0.02$ & $98.2 \pm 0.5$ & $6.2 \pm 0.2$ & $16 \pm 0.4$ & $6.6 \pm 0.32$ \\
\hline $\mathrm{F} 4$ & $71.86 \pm 0.4$ & $0.16 \pm 0.01$ & $100.5 \pm 0.2$ & $6.2 \pm 0.3$ & $300 \pm 0.6$ & $9.4 \pm 0.1$ \\
\hline F5 & $61.4 . \pm 0.6$ & $0.13 \pm 0.02$ & $100 \pm 0.1$ & $6.1 \pm 0.2$ & $108 \pm 0.4$ & $5.8 \pm 0.25$ \\
\hline F6 & $61.9 \pm 0.05$ & $0.12 \pm 0.04$ & $101 \pm 0.2$ & $6.2 \pm 0.3$ & $78 \pm 0.1$ & $7.2 \pm 0.2$ \\
\hline F7 & $53.63 \pm 0.2$ & $0.11 \pm 0.01$ & $99.9 \pm 0.1$ & $6.3 \pm 0.5$ & $7 \pm 0.5$ & $4.4 \pm 0.3$ \\
\hline F8 & $51.8 \pm 0.6$ & $0.09 \pm 0.02$ & $98.1 \pm 0.2$ & $6.2 \pm 0.4$ & $10 \pm 0.5$ & $4.2 \pm 0.32$ \\
\hline F9 & $52.2 \pm 0.02$ & $0.08 \pm 0.05$ & $102.2 \pm 0.2$ & $6.0 \pm 0.5$ & $12 \pm 0.4$ & $5.1 \pm 0.6$ \\
\hline F10 & $52.28 \pm 0.1$ & $0.09 \pm 0.02$ & $96 \pm 0.4$ & $6.5 \pm 0.1$ & $15 \pm 0.5$ & $6.0 \pm 0.45$ \\
\hline F11 & $52.0 \pm 0.5$ & $0.09 \pm 0.03$ & $101 \pm 0.1$ & $6.2 \pm 0.4$ & $10 \pm 0.2$ & $5.09 \pm 0.3$ \\
\hline F12 & $52.5 \pm 0.06$ & $0.09 \pm 0.03$ & $96.8 \pm 0.4$ & $6.3 \pm 0.1$ & $11 \pm 0.2$ & $4.8 \pm 0.6$ \\
\hline F13 & $55.32 \pm 0.01$ & $0.09 \pm 0.02$ & $100 \pm 0.01$ & $6.2 \pm 0.2$ & $7 \pm 0.5$ & $5.0 \pm 0.25$ \\
\hline F14 & $51.32 \pm 0.01$ & $0.08 \pm 0.01$ & $98.6 \pm 0.2$ & $6.3 \pm 0.1$ & $9.8 \pm 0.2$ & $4.4 \pm 0.3$ \\
\hline
\end{tabular}

All values were calculated as mean $\pm S D,{ }^{*} n=3,{ }^{* *} n=6,{ }^{* * *} \mathrm{n}=10$ 
Table 3: Mechanical properties of lafutidine OFDFs formulas

\begin{tabular}{lllll}
\hline Formula code & Folding endurance & Tensile strength & Percent of elongation & Young's modulus. \\
\hline F1 & $450 \pm 5.5$ & $6.5 \pm 0.2$ & $21.1 \pm 0.2$ & $105 \pm 0.3$ \\
F2 & $500 \pm 4.5$ & $16 \pm 0.1$ & $28.3 \pm 0.6$ & $110.6 \pm 0.4$ \\
F3 & $800 \pm 6.4$ & $19 \pm 0.12$ & $30.1 \pm 0.5$ & $116 \pm 0.8$ \\
F4 & $600 \pm 10$ & $22 \pm 0.8$ & $28 \pm 0.8$ & $120 \pm 2.5$ \\
F5 & $800 \pm 8.0$ & $18 \pm 0.5$ & $26 \pm 0.5$ & $116 \pm 3.1$ \\
F6 & $1200 \pm 12$ & $20 \pm 0.3$ & $32 \pm 0.6$ & $118 \pm 1.5$ \\
F7 & $600 \pm 3.4$ & $4.6 \pm 0.4$ & $25.5 \pm 0.3$ & $19.8 \pm 0.8$ \\
F8 & $400 \pm 2.6$ & $6.1 \pm 0.3$ & $14.2 \pm 0.6$ & $102 \pm 0.2$ \\
F9 & $150 \pm 1.5$ & $5.2 \pm 0.4$ & $18.5 \pm 0.3$ & $11.5 \pm 0.8$ \\
F10 & $380 \pm 2.5$ & $7.6 \pm 0.5$ & $17.4 \pm 0.2$ & $112.5 \pm 0.5$ \\
F11 & $400 \pm 3.5$ & $8.2 \pm 0.7$ & $18.6 \pm 0.2$ & $115.4 \pm 0.3$ \\
F12 & $370 \pm 1.5$ & $4.4 \pm 0.2$ & $18.9 \pm 0.6$ \\
F13 & $359 \pm 2.0$ & $5.4 \pm 0.1$ & $17.5 \pm 0.6$ \\
F14 & $480 \pm 0.6$ & $4.4 \pm 0.2$ & $86.8 \pm 0.5$ \\
\hline
\end{tabular}

All values were calculated as mean $\pm S D, n=3$

\section{Effect of different types of polymers}

As shown in table 1 formulas (F1, F2 and F3) were utilized to study the effect of polymer type (HPMC E5, PVA, and SCMC) with concentration $(50 \% \mathrm{w} / \mathrm{w}$ of the total dry weight) on the physical and mechanical properties of the prepared lafutidine OFDFs as well as their effect on the drug release profile.

According to the results obtained, potential differences could be investigated between the three polymers without changing their ratio in the prepared film, also variation in the DT and mechanical characteristics could be identified in order to select the polymer that has the best film forming properties. The mechanical properties of OFDFs are very essential since it related to their stability during storage, shipping, and packaging.

A high \% E value shows that the film is flexible and tough. Tensile strength has been utilized as a marker of the general mechanical prevalence of the film. Folding endurance test results indicated that the films would maintain the integrity with buccal mucosa when applied and has good plasticity. This makes the system acceptable for movement of the mouth, indicating good strength and elasticity. The selected OFDFs must have reasonable tensile strength, high \% E, low young's modulus, short DT and a high percent of drug release.

The results in the table 2 showed that the DT of formulas F1, F2 and $\mathrm{F} 3$ were 8,10 and $16 \mathrm{~s}$ respectively, this indicates that $\mathrm{F} 1$ gave the shortest DT in the mouth compared to the other formulas [25]. Except for PVA the retardation in disintegration is due to the swelling property of this polymer which makes a gel-like layer on the surface of the film upon contact with aqueous media leads to preventing penetration of water to the film, this swelling property increased with increasing the polymer concentration [26].

So different film-forming polymers gave different DT value as shown in the fig. 1:

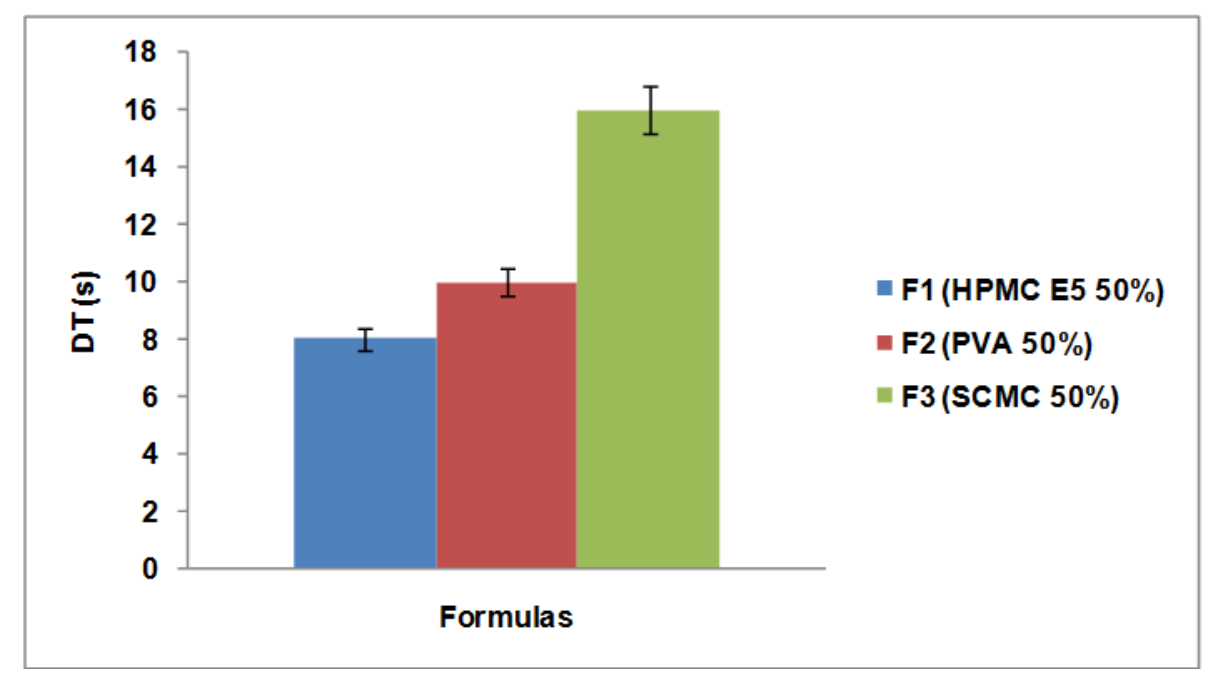

Fig. 1: In vitro disintegration time of different film-forming polymers, (mean $\pm S D, n=3)$

As expressed in table 3 in which the mechanical properties of OFDFs are listed, the film prepared with HPMC E5 (F1) as film-forming polymer gave satisfactory \% E (21.1 \pm 0.2$)$, excellent folding endurance value $(450 \pm 5.5)$, with low value of young's modulus $(105 \pm 0.3)$ and the tensile strength, is about $(6.5 \pm 0.2)$, these outcomes were in concurrence with those that reported by Tamer et al. [27].

Formula F2 prepared with PVA as film-forming polymer exhibited a

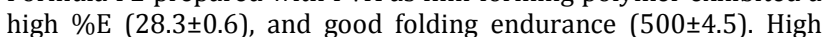
values of young's module and tensile strength were (110.6 \pm 0.4$)$ and $(16 \pm 0.1)$ respectively while the films prepared with SCMC as film forming polymer exerts higher values of folding endurance $(800 \pm 6.4), \% \mathrm{E}(30.1 \pm 0.5)$, Young's modulus $(116 \pm 0.8)$ and tensile strength $(19 \pm 0.12)$ as shown in table 3 . These findings agreed with the results reported by Chinnala et al. [28].

Fig. 2 showed the dissolution profile of formulas (F1, F2 andF3), it was clear that the cumulative percentage of lafutidine released from the investigated polymers would be as follow: $\mathrm{F} 1>\mathrm{F} 2>\mathrm{F} 3$.

The difference in dissolution may be attributed to the difference in composition of film-forming materials [25]. 


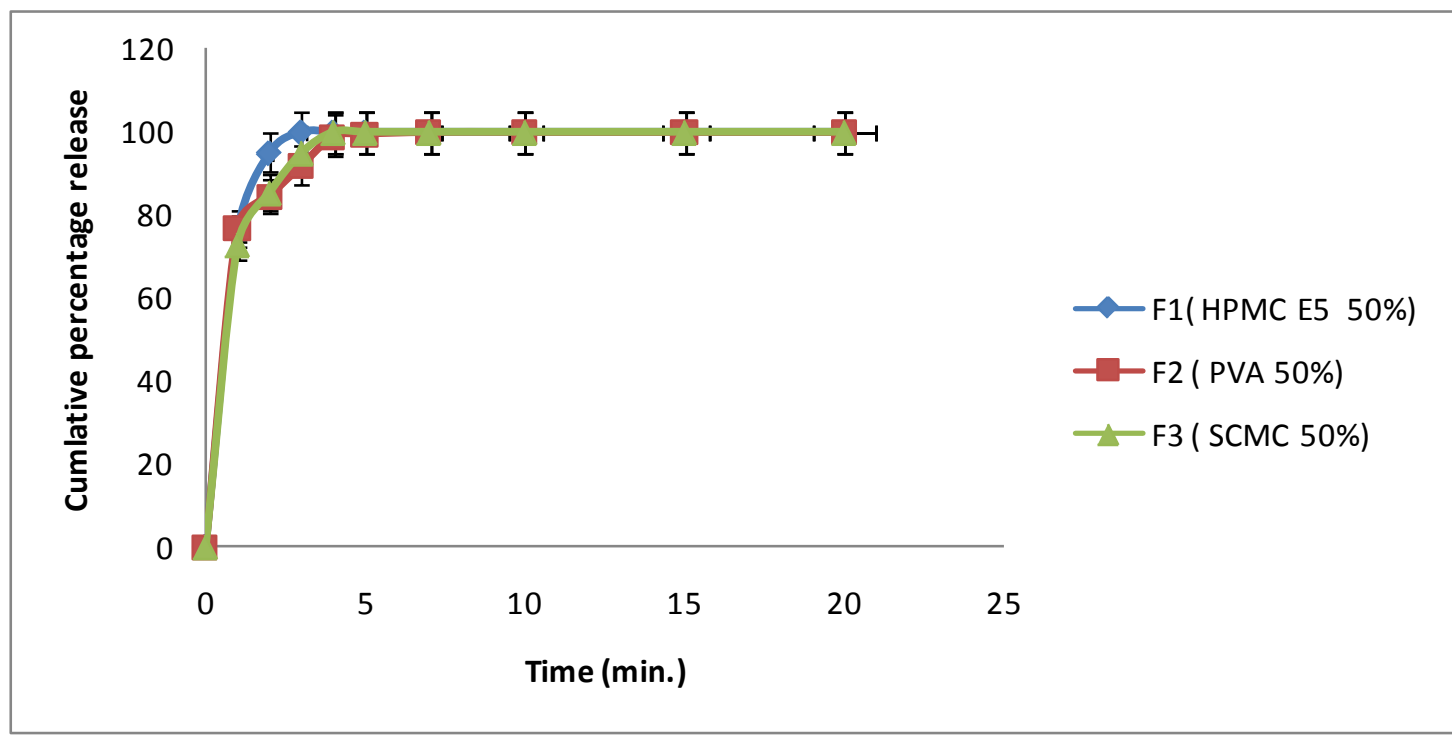

Fig. 2: Effect of polymer type on the dissolution profile of lafutidine in phosphate buffer $(\mathrm{pH} 6.8)$ at $37^{\circ} \mathrm{C},(\mathrm{mean} \pm \mathrm{SD}, \mathrm{n}=3)$

The values of $\mathrm{T} 80 \%$ (time needed for $80 \%$ of medication to be released) for F1, F2 and F3 were 1.68, 1.9 and 1.87, min respectively, as well as the values of \% D2 min (percentage medication released in $2 \mathrm{~min}$ ) were $95 \%, 84 \%$ and $85.4 \%$ respectively as listed in table 4 .

Table 4: In vitro dissolution parameters from the prepared OFDFs (F1, F2 and F3)

\begin{tabular}{lll}
\hline Formula & T80\% (min) & D2 min (\%) \\
\hline F1 & $1.68 \pm 0.1$ & $95 \pm 0.2$ \\
F2 & $1.9 \pm 0.15$ & $84 \pm 0.25$ \\
F3 & $1.87 \pm 0.2$ & $85.4 \pm 0.4$ \\
\hline
\end{tabular}

All values were calculated as mean $\pm \mathrm{SD}, \mathrm{n}=3$, from all these results we found that HPMC E5 (F1) had the best physical, mechanical properties and drug release profile than the other film forming polymers.

\section{Effect of selected polymer (HPMC E5) combination}

According to the physical, mechanical properties, and the drug release profile, HPMC E5 (F1) was selected as an optimized suitable polymer for preparing of lafutidine OFDF.

Formulas F4, F5 (HPMC E5 with PVA in a ratio of 1:1 and 1:0.5 respectively) and F6 (HPMC E5 with SCMC in 1: 0.5 ratio) were further evaluated to get an optimum suitable polymer combination by studying their physical, mechanical and the dissolution profile parameters.
Table 2 revealed that there is a significantly $(p \leq 0.05)$ increased in the in vitro DT of the formulated OFDFs with increasing the ratio of polymer combination with HPMC E5 from F4>F5>F6.

Fig. 3 showed that films containing a high concentration of polymer (HPMC E5 with PVA) resulted in a thicker gel upon contact with the medium, leading to longer DT except for SCMC with HPMC E5 which is more water soluble than PVA in the same ratio [29]. This was agreed with the result obtained from metoprolol tartrate strips and lamotrigine fast dissolving films [30,31].

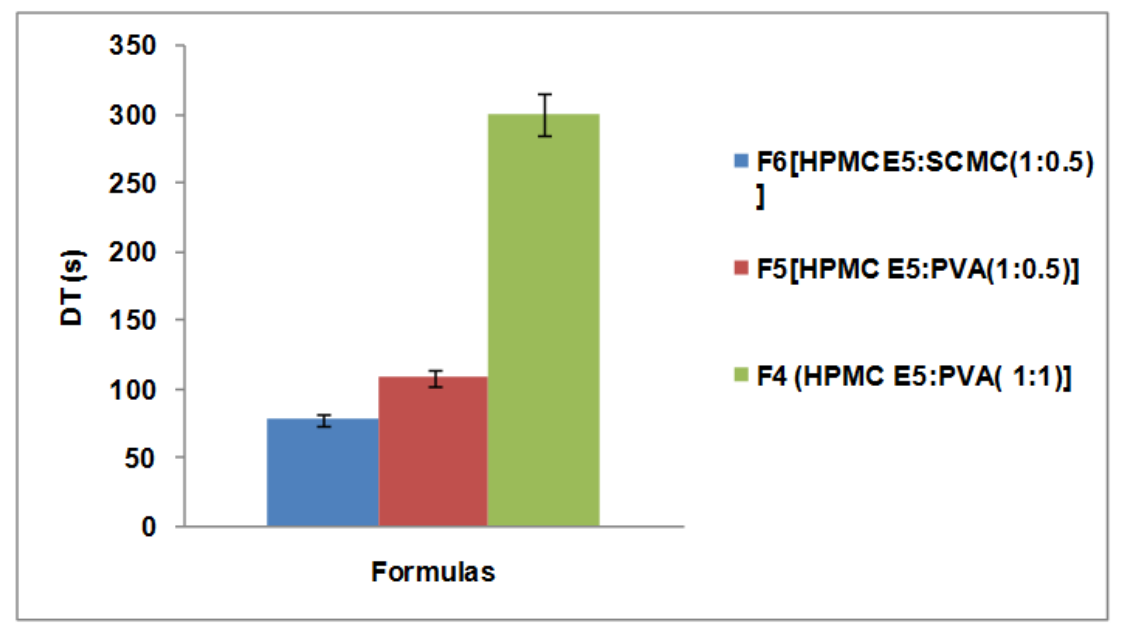

Fig. 3: In vitro disintegration time of different polymer combination with the selected film-forming a polymer (HPMC E5), (mean \pm SD, $n=3$ ) 
The outcomes listed in table 3, indicate that film with high value of tensile strength result from increasing the polymer concentration is due to the fact that densely packed chains of HPMC produced from polymer combination make the film need more force to breaks [32]. These findings agreed with the results obtained by Kazan et al. [33].

Also high \% $\mathrm{E}$ and higher folding endurance of the films were detected upon a combination of polymers as shown in table 3 ,which is due to increase in the elasticity nature of the polymer [28]. Similar observations were found by Trivedi J et al. [34].

Table 5 shows that formula (F1) has the highest D2 min (95\%) and the lowest $\mathrm{T} 80 \%$ (1.68 $\mathrm{min}$ ) indicating that $\mathrm{F} 1$ which formulated only with HPMC E5 as a film-forming polymer gave fastest dissolution rate compared with the F4, F5 and F6 which formulated using different ratio of polymer combination with HPMC E5.

Table 5: In vitro dissolution parameters from the prepared OFDFs (F1, F4, F5, and F6)

\begin{tabular}{lll}
\hline Formula code & T80\% (min) & D2 min (\%) \\
\hline F1 & $1.68 \pm 0.5$ & $95 \pm 0.2$ \\
F4 & $6.9 \pm 0.5$ & $70.6 \pm 0.2$ \\
F5 & $2.9 \pm 0.25$ & $78 \pm 0.55$ \\
F6 & $2.94 \pm 0.3$ & $76.3 \pm 1.25$ \\
\hline
\end{tabular}

All values were calculated as mean $\pm \mathrm{SD}, \mathrm{n}=3$

From the dissolution parameters that shown in table 5 for the formulas (F1, F4, F5 and F6) prepared with a different combination ratio of each polymers (PVA, SCMC) with HPMC E5,it was clear that the dissolution rate of lafutidine reduces significantly $(\mathrm{p}<0.05)$ as the ratio of polymer combination with HPMC E5 increases from 1: zero in formula (F1) to $1: 1$ in formula (F4) as shown in fig. 4, this result may be due to the fact that higher concentration of polymers, produce a high consistency gel layer created by close interaction between the particles resulting in a diminished movement of medication particles in swollen lattices, which prompt a decline in dissolution rate [32]

The percentage of lafutidine released from the investigated polymer combination would be higher for formula as follow: F1 $>\mathrm{F} 6>\mathrm{F} 5>\mathrm{F} 4$.

Therefore, F1 which contain only HPMC E5 $(50 \% \mathrm{w} / \mathrm{w})$ with $0 \%$ of other polymers was considered as the best polymer chosen for the design of the subsequent formulas through the study.

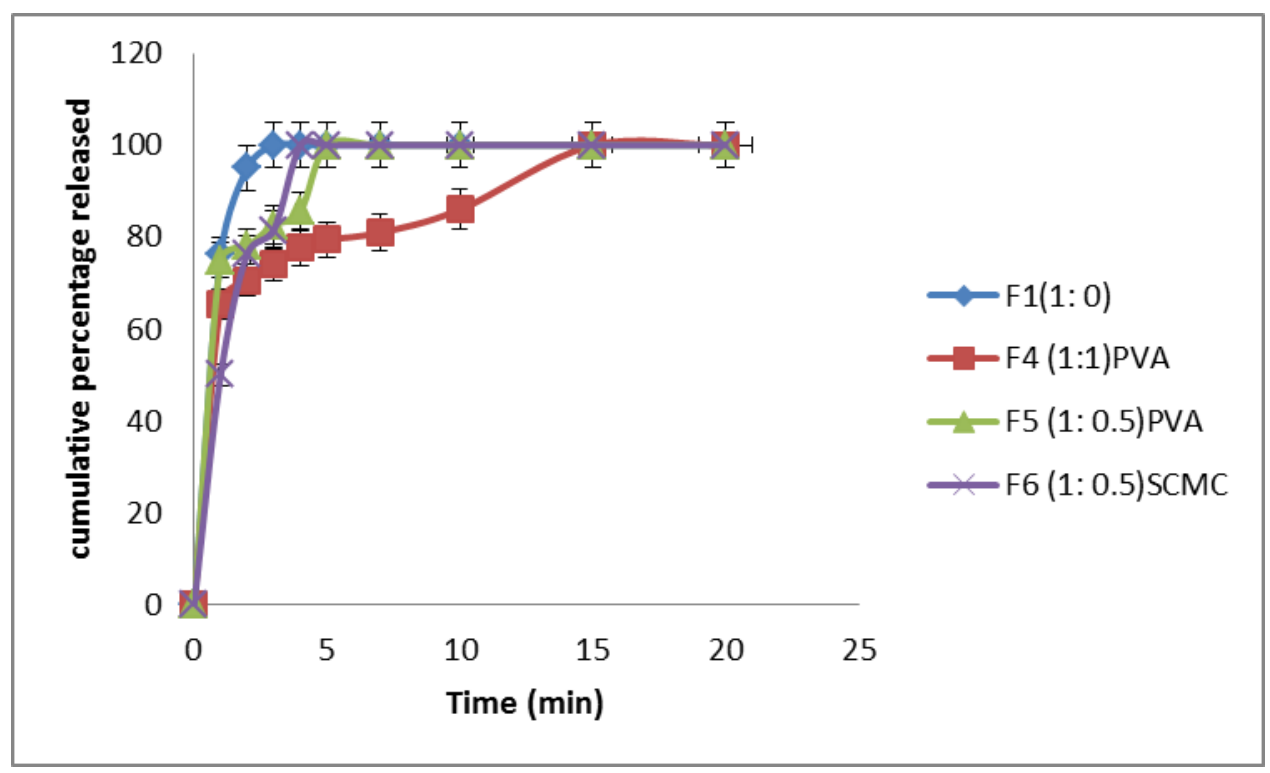

Fig. 4: Cumulative percentage of lafutidine released from different combination of polymer with HPMC E5 in phosphate buffer (pH 6.8) at $37^{\circ} \mathrm{C},($ mean $\pm S D, n=3)$

\section{Effect of the plasticizer type}

Formulas (F1, F10, and F11) were employed to study the effect of different plasticizer types at a certain concentration $30 \% \mathrm{w} / \mathrm{w}$ (PEG 400 , glycerin, and PG) on the physical and mechanical properties of the prepared lafutidine OFDFs as well as their effect on the drug release profile.

The results indicate that no significant changes $(p>0.05)$ were shown on the in vitro DT of the OFDF upon changing of plasticizer type as shown in fig. 5, this may be due to the fact that penetration of fluid into the film was facilitated by the three types of plasticizer since the densely packed chains of HPMC were altered by the plasticizer through forming a polymer structure possess more pores and less densely that breaks at lower force, resulting in faster disintegration of the film [35].
Higher value of folding endurance was shown for PEG 400 containing formula compared with the others. On the other hand, soft and tough film was made with glycerin while PG produced the patchy and sticky film. At the same time, film plasticized with PEG 400 exhibited good physical and mechanical properties such as tensile strength and $\% \mathrm{E}$ as shown in table 3 . These observations are in accordance with Ali MS et al. [36] and Choudhary et al. [37].

So PEG400 was selected for further study for suitability in films formulation.

$\mathrm{T} 80 \%$ and $\% \mathrm{D} 2$ min from the formulated films (F1, F10 and F11) are listed below in table 6 .

The release profile of lafutidine from formulas (F1, F10 and F11) which contain $30 \% \mathrm{w} / \mathrm{w}$ of (PEG 400 , glycerin and PG) respectively 
is displayed in fig. 6. No significant change $(p>0.05)$ on the dissolution profile was seen by changing the plasticizer type because all the three plasticizers are water soluble, and they will diffuse out from the films in watery media making void spaces in the film through which diffusion of liquid happened enabling film breaking down leading to improve release profile of drug [38].



Fig. 5: In vitro disintegration time in seconds of formulas prepared with different types of plasticizer, $(\operatorname{mean} \pm S D, n=3)$

Table 6: In vitro dissolution parameters from the prepared OFDFs (F1, F10 and F11)

\begin{tabular}{lll}
\hline Formula code & T80\% (min) & D2 $\mathbf{m i n}(\mathbf{\%})$ \\
\hline F1 & $1.68 \pm 0.5$ & $95 \pm 0.2$ \\
F10 & $1.86 \pm 0.2$ & $86 \pm 0.55$ \\
F11 & $1.8 \pm 0.15$ & $90 \pm 0.8$ \\
\hline
\end{tabular}

All values were calculated as mean $\pm \mathrm{SD}, \mathrm{n}=3$

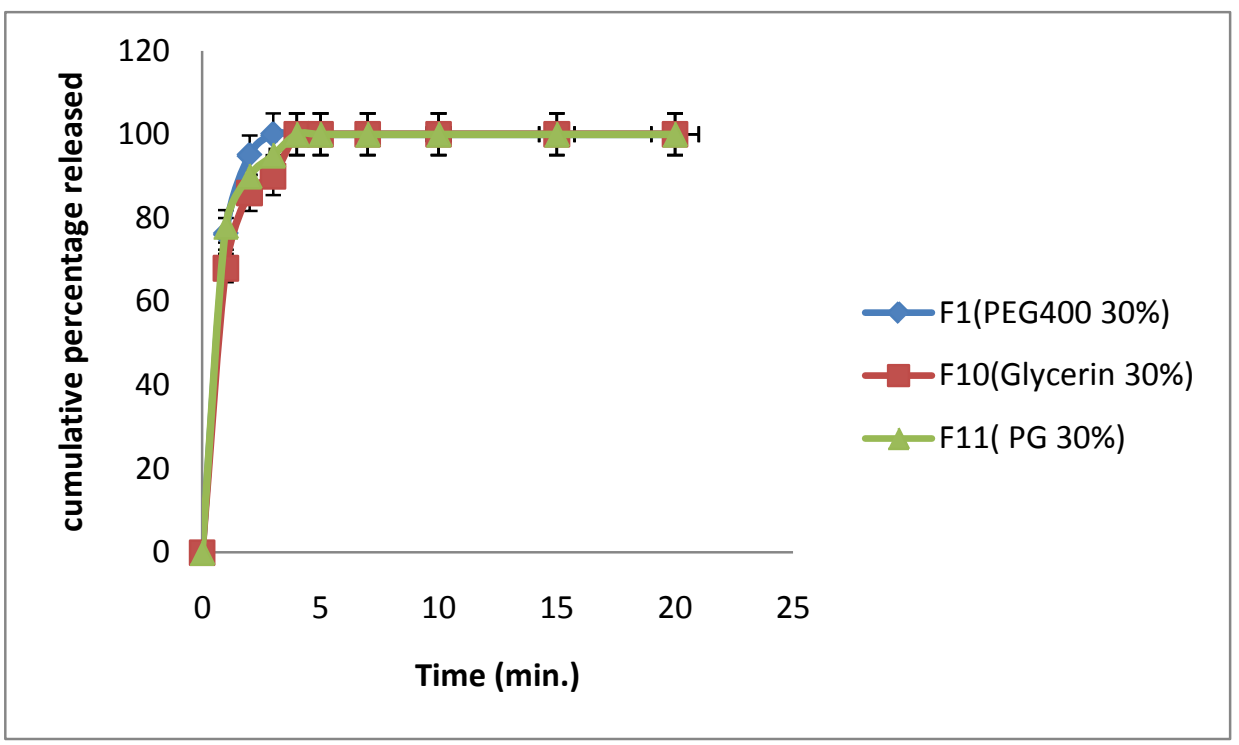

Fig. 6: Cumulative percentage of lafutidine released from formulas prepared with different types of plasticizer in phosphate buffer (pH 6.8) at $37^{\circ} \mathrm{C},($ mean $\pm S D, n=3)$

\section{Effect of the selected plasticizer concentration}

Formulas (F1, F7, F8 and F9) were used to study the effect of different concentrations of selected plasticizer PEG400 (30, 34, 24 and $16 \% \mathrm{w} / \mathrm{w}$ of the total film weight) on the in vitro DT, mechanical properties and the drug release profile of the oral film.
Formulas (F1, F7, F8 and F9) showed that increasing the concentration of the selected plasticizer (PEG400) accompanied with decreasing in the DT as shown in fig. 7, this is due to the effect of PEG 400 as co-solvent which increases the solubility of non-polar, hydrophobic compounds by reducing the water squeezing out of them [39]. 


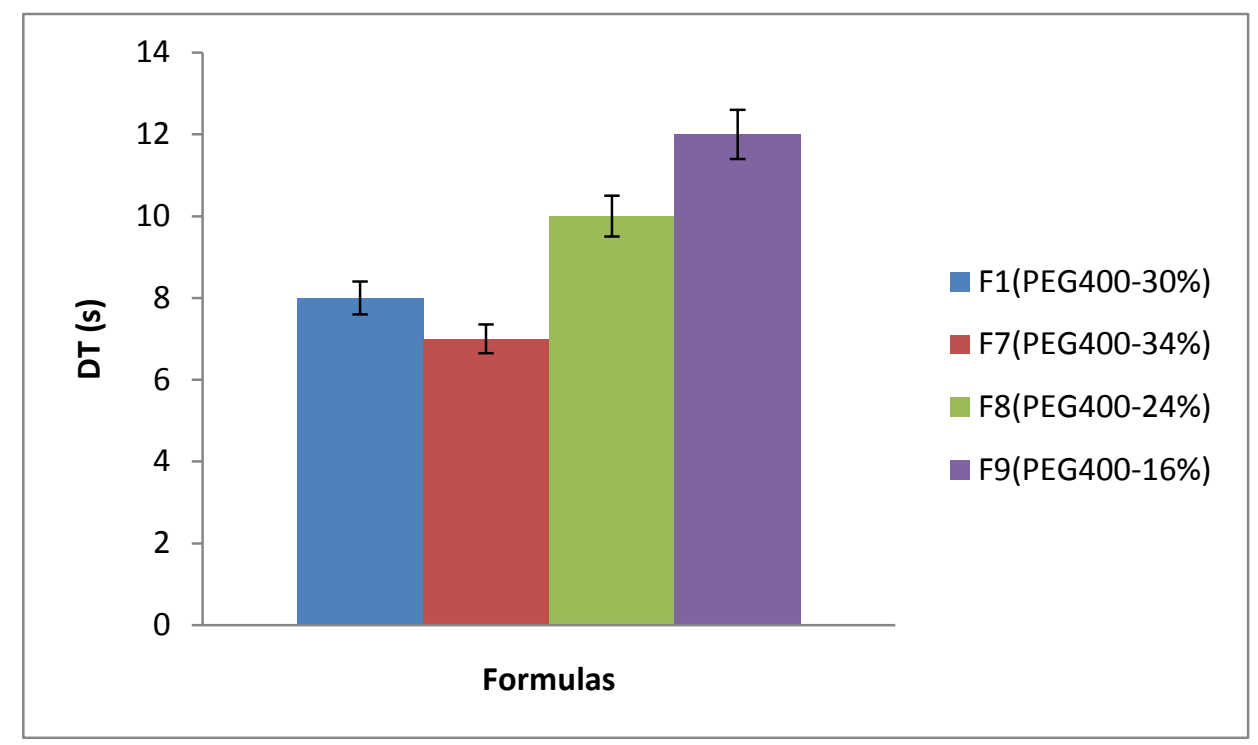

Fig. 7: In vitro disintegration time in seconds of formulas prepared with the different concentration of the selected plasticizer (PEG 400), $($ mean $\pm S D, n=3)$

The mechanical properties of formulas (F1, F7, F8 and F9) were shown in table 3, which illustrated that as the plasticizer concentration increased the young's modulus and the tensile strength decreased. This is due to the fact that the intermolecular forces between polymer chains weakened upon increasing the concentration of plasticizer thus the rigidity of the threedimensional structure formed upon drying decreased [27].

Moreover, the \%E was increased with increasing plasticizer concentration. These results can be explained by the (lubricity theory) which states that the plasticizers act as an interior emollient and enhance movement of the polymer chains [40].

The release profile of lafutidine from formulas (F1, F7, F8 and F9) which contain $30,34,24$ and $16 \%$ w/w of PEG 400 respectively were shown in fig. 8, it was observed that as the concentration PEG 400 increased the drug release rate significantly increased $(\mathrm{p}<0.05)$ this was explained by the role of PEG 400 as a facilitating dissolution agent [41].



Fig. 8: Cumulative percentage of lafutidine released from formulas prepared with the different concentration of PEG400 in phosphate buffer ( $\mathrm{pH} 6.8)$ at $37^{\circ} \mathrm{C}$, $($ mean $\pm \mathrm{SD}, \mathrm{n}=3)$

$\mathrm{T} 80 \%$ and $\% \mathrm{D} 2 \mathrm{~min}$ from the formulated films (F1, F7, F8 and F9) are listed below in table 7.

Table 7: In vitro dissolution parameters from the prepared OFDFs (F1, F7, F8 and F9)

\begin{tabular}{lll}
\hline Formula code & T80\% (min) & D2 $\mathbf{m i n}(\mathbf{\%})$ \\
\hline F1 & $1.68 \pm 0.5$ & $95 \pm 0.2$ \\
F7 & $1.95 \pm 0.3$ & $82.7 \pm 0.8$ \\
F8 & $2.93 \pm 0.25$ & $70 \pm 0.65$ \\
F9 & $3.9 \pm 0.35$ & $64 \pm 0.4$ \\
\hline
\end{tabular}

All values were calculated as mean $\pm S D, n=3$, from the above results concerning physical, mechanical evaluations and release profile of the prepared OFDFs using different plasticizer types and concentrations. F1 will be subjected for the forward study. 


\section{Effect of surfactant type and combination}

Formulas (F1, F12 and F13) were used to study the effect of different types of surfactant (tween80, poloxamer407 and combination of both) on the in vitro DT, mechanical properties and the drug release profile of the OFDFs.

Fig. 9 showed that the DT is significantly affected $(\mathrm{p}<0.05)$ by the type of surfactant so the best result (7 s) was obtained from F13 upon a combination of the two types of surfactants (tween80 and poloxamer407) [42].

The mechanical properties of formulas (F1, F12 and F13) were listed in table 3 , all the values of folding endurance, tensile strength, \%E and young's modulus were within the range of accepted OFDFs.

The release profile of lafutidine from formulas F1, F12 and F13 which contain tween80, poloxamer407 and combination of both surfactants, respectively was shown in fig. 10. It was observed that combination of surfactants(F13) significantly $(\mathrm{p}<0.05)$ increased the release of the drug from OFDFs, this is due to the additive effect of the water-soluble surfactant (poloxamer 407) which increases the solubility of the drug with a hydrophilic surfactant (tween80) that acts by decreasing surface tension and increasing wettability of the drug $[12,43]$.

The $\mathrm{T} 80 \%$ and $\% \mathrm{D} 2$ min values for formulas (F1, F12, and F13) were illustrated below in table 8.

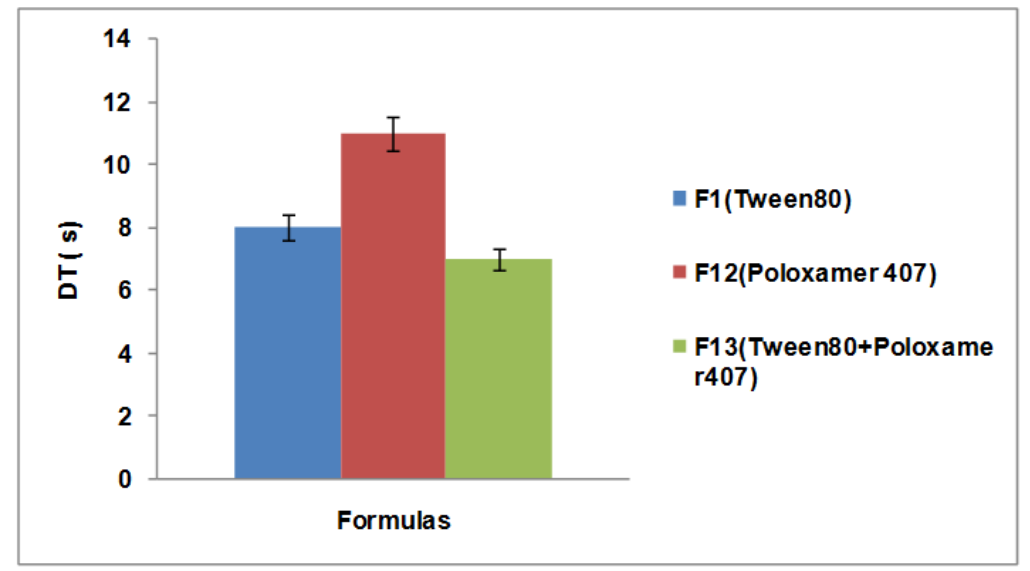

Fig. 9: In vitro disintegration time in seconds of formulas prepared with different types of surfactant (tween80, poloxamer407), (mean $\pm S D, n=3$ )

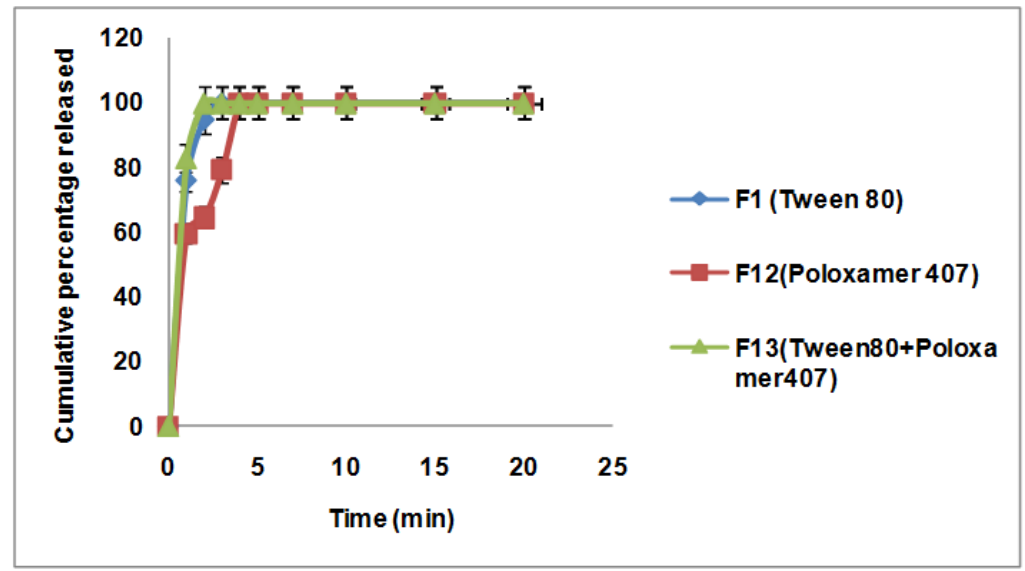

Fig. 10: Cumulative percentage of lafutidine released from formulas prepared with different types of surfactant in phosphate buffer (pH 6.8) at $37^{\circ} \mathrm{C},($ mean $\pm S D, n=3)$

Table 8: In vitro dissolution parameters from the prepared OFDFs (F1, F12 and F13)

\begin{tabular}{lll}
\hline Formula code & T80\%(min) & D2 $\mathbf{m i n}(\mathbf{\%})$ \\
\hline F1 & $1.68 \pm 0.5$ & $95 \pm 0.2$ \\
F12 & $3.7 \pm 0.3$ & $64.6 \pm 0.8$ \\
F13 & $0.96 \pm 0.25$ & $100 \pm 0.1$ \\
\hline
\end{tabular}

All values were calculated as mean $\pm \mathrm{SD}, \mathrm{n}=3$, Formula (F13) was chosen as the best one and can be further evaluated throughout the study depending on the previous outcomes that gave shorter DT, lower T $80 \%$,maximum D2 min and satisfactory mechanical properties.

\section{Effect of superdisintegrant}

Formulas F13 and F14 listed in table 1 which contain croscarmellose $5 \%$ and $0 \%$ respectively were allowed to study the DT and the release profile.
Fig. 11 showed that croscarmellose significantly decreased $(p<0.05)$ the DT of the OFDFs, this owing to the great capillary action of the superdisintegrant which quickly absorbs water into the film, swelling then giving a fast disintegration. 


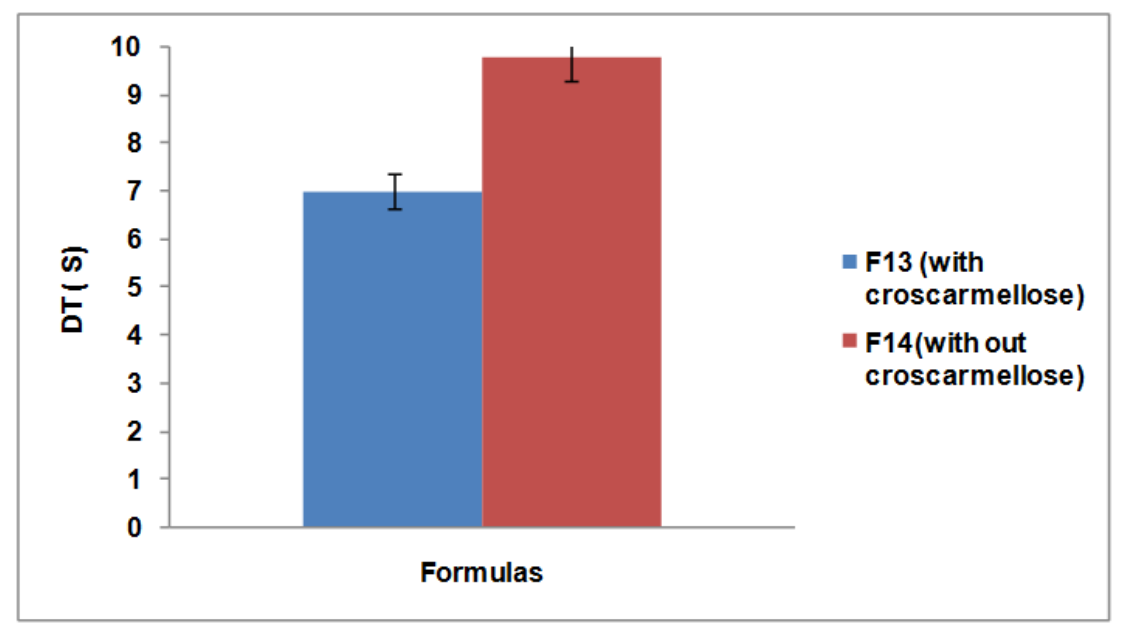

Fig. 11: In vitro disintegration time in seconds of formulas prepared with and without croscarmellose as a super disintegrant, (mean $\pm S D, n=3)$

Fig. 12 showed the effect of croscarmellose on the release profile of lafutidine from formulas F13 (with superdisintegrant) and F14 (without superdisintegrant). Faster release $(\mathrm{p}<0.05)$ was observed for F13 in comparison with F14 which is due to the highly porous structure of the superdisintegrant particles, help them to wick the liquid, swelling then break down and release of the drug $[44,45]$

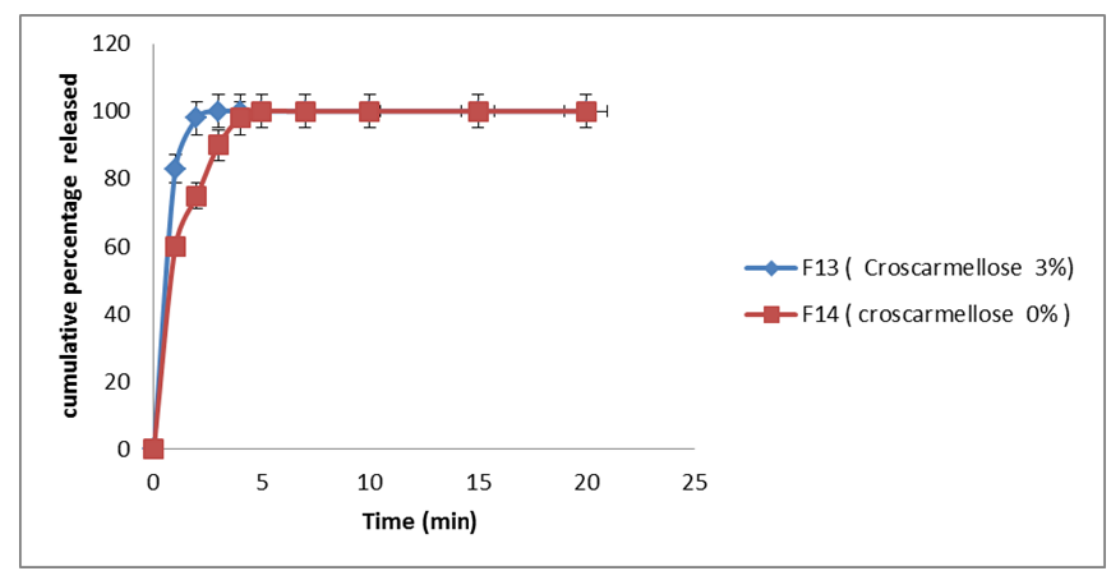

Fig. 12: Cumulative percentage of lafutidine released from formulas prepared with and without croscarmellose as superdisintegrant in phosphate buffer (pH 6.8) at $37^{\circ} \mathrm{C}$, (mean $\left.\pm \mathrm{SD}, \mathrm{n}=3\right)$

The $\mathrm{T}_{80 \%}$ and \% D2 min values for formulas (F13 and F14) were illustrated in table 9 below.

Table 9: In vitro dissolution parameters from the prepared OFDFs (F13 and F14)

\begin{tabular}{lll}
\hline Formula code & T80\% ( $\min )$ & D2 $\mathbf{m i n}(\mathbf{\%})$ \\
\hline F13 & $0.96 \pm 0.25$ & $100 \pm 0.1$ \\
F14 & $2.13 \pm 0.4$ & $75 \pm 0.6$ \\
\hline
\end{tabular}

All values were calculated as mean $\pm \mathrm{SD}, \mathrm{n}=3$, From the previous results F13 which shown below in the fig. 13 was selected as the best formula for preparing of lafutidine as OFDF.

Fig. 13: The best-selected formula F13 


\section{CONCLUSION}

According to the results obtained; HPMC E5 showed the shortest in vitro DT accompanied with acceptable mechanical properties and dissolution behavior. PEG400 was the best plasticizer as it showed an improvement in the mechanical and physical characteristics of the lafutidine OFDFs. Formula (F13) which composed from 50\% $\mathrm{w} / \mathrm{w}$ HPMC E5 as a film forming polymer, 30\% PEG400 as a plasticizer, $3.2 \%$ of each poloxamer 407 and tween 80 as surfactants, finally $3 \%$ croscarmellose added as superdisintegrant. This is regarded as an optimized formula with a low DT $(7 \pm 0.5 \mathrm{~s})$ and $80 \%$ of drug released within (0.96 min)

When lafutidine administered in the form of OFDFs will be a potential novel drug dosage form for geriatric by providing faster release and better patient compliance.

\section{ACKNOWLEDGMENT}

We are very thankful to the research and material department/ Ministry of Science and Technology, College of Pharmacy/University of Baghdad, Iraq, for providing the necessary facilities that help to complete our work.

\section{AUTHORS CONTRIBUTIONS}

All the authors have contributed equally

\section{CONFLICTS OF INTERESTS}

Declared none

\section{REFERENCES}

1. Patel D, Patel M, Upadhyay P, Shah N, Shaha S. A review on mouth dissolving film. J Pharm Sci Bio Res 2015;5:266-73.

2. Nair V, Saudagar RB, Gondkar SB. A review on fast dissolving sublingual films for systemic drug delivery. World J Phar Pharm Sci 2015;4:342-61.

3. Banarjee T, Ansari VA, Singh S, Mohmood T, Akhtar J. A review on fast dissolving films for buccal delivery of low doses drugs. Int J Leg Stu Res 2015;1:117-23.

4. Singh G, Saini S, Gill NS. Oral fast dissolving films: an innovative drug delivery system. Int J Univ Pharm Bio Sci 2014;3:163-77.

5. Moorkoth S, Kumar S, Pai A, Kamath V. Stability is indicating analytical method development and validation of lafutidine in tablet dosage form by RP-HPLC. Min J Pharm Med Sci 2013;2:18-21.

6. Reddy MB, Hari B. Determination of lafutidine through oxidative coupling reaction in bulk sample and dosage forms-a new approach. Int J Pharm Sci Res 2016;6:2626-30.

7. Ikawa K, Shimatani T, Hayato S, Morikawa N, Tazuma S. Pharmacokinetic and pharmacodynamic properties of lafutidine after postprandial oral administration in healthy subjects: comparison with famotidine. Biol Pharm Bull 2007;30:1003-6.

8. Yamagishi H, Koike T, Ohara S, Horii T, Kikuchi R, Kobayashi S, et al. Stronger inhibition of gastric acid secretion by lafutidine, a novel $\mathrm{H} 2$ receptor antagonist, than by the proton pump inhibitor lansoprazole. World J Gastroenterol 2008;14:2406-10.

9. Dewan B, Chimata R. An open-label, randomized, cross-over bioequivalence study of lafutidine $10 \mathrm{mg}$ under fasting condition. World J Gastrol Pharmacol Ther 2010;1:112-8.

10. Onodera S, Shibata M, Tanaka M, Inaba N, Yamaura T, Ohnishi H. Gastroprotective activity of FRG-8813, a novel histamine H2receptor antagonist, in rats. Japan J Pharmacol 1995;68:161-73.

11. Dawood NM, Abd-Al hammid SHN, Hussien AA. Formulation and characterization of lafutidine nanosuspension for oral drug delivary system. Int J Appl Pharm Sci 2018;10:20-30.

12. Noor AH, Khalil YI. Formulation and evaluation of felodipine orodispersible films. Pharm Glob 2015;6:1-16.

13. Bhikshapathi DVRN, Madhuri VD, Rajesham VV, Suthakaran R. Preparation and evaluation of fast dissolving oral film containing naratriptan HCl. Am J Pharm Tech Res 2014;4:799-812.

14. Sri KV, Rohini P, Reddy GK. Montelukast sodium oral thin films: formulation and in vitro evaluation. Asian J Pharm Clin Res 2012;5:266-70.
15. Raju S, Reddy PS, Kumar VA, Deepthi A, Reddy KS, Reddy PM, et al. Flash release oral films of metoclopramide hydrochloride for pediatric use: formulation and in vitro evaluation. J Chem Pharm Res 2011;3:636-46.

16. Jadhav K, Dhamecha D, Tate A, Tambe H, Patil MB. Application of UV spectrophotometric method for easy and rapid estimation of lafutidine in bulk and pharmaceutical formulation. Pharm Methods 2011;2:264-7.

17. Sultana F, Arafat M, Pathan SI. Preparation and evaluation of fast dissolving oral thin film of caffeine. Int J Pharm Biol Sci 2013;3:153-61.

18. Pathan A, Gupta MK, Jain NK, Dubey A, Agrawal A. Formulation and evaluation of fast dissolving oral film of promethazine hydrochloride using a different surfactant. J Inno Pharm Bio Sci 2016;3:74-84.

19. Maheswari KM, Devineni PK, Deekonda S, Shaik S, Uppala NP, Nalluri BN. Development and evaluation of mouth dissolving films of amlodipine besylate for enhanced therapeutic efficacy. J Pharm 2014;3:1-10.

20. Nalluri BN, Sravani B, Anusha VS, Sribramhini R, Maheswari KM. Development and evaluation of mouth dissolving films of sumatriptan succinate for better therapeutic efficacy. J Appl Pharm Sci 2013;3:161-6.

21. Vijayakumar S, Gavaskar B. Overview on fast dissolving films. Int J Pharm Pharm Sci 2010;2:293-317.

22. Remidi T, Prasanna K, Mohanty D, Spandana M, Ratnapuram RS. Formulation and in vitro evaluation of oral thin film of mirtazapine. Int J Invent Pharm Sci 2014;2:844-9.

23. Preis M, Pein M, Breitkreutz J. Development of a taste-masked orodispersible film containing dimenhydrinate. Pharmaceutics 2012;4:551-62.

24. Geedi V, Roy SD, Reddy PV. Formulation and evaluation of fast dissolving oral films of zolmitriptan by natural polymers. Int J Adv Pharm 2014;4:57-63.

25. Radhi AA, Kamal BA. Formulation and in vitro evaluation of ketotifen fumarate oral strips. Int J Sci-Tech 2012;7:53-63.

26. Tomar A, Sharma K. Formulation, and evaluation of fast dissolving film of dicyclomine as a potential route of buccal delivery. In J Drug Dev Res 2012;4:408-17.

27. Tamer MA, Abd-Al Hammid SHN, Ahmed B. Formulation and in vitro evaluation of bromocryptine mysylate as fast dissolving oral film. Int J Appl Pharm Sci 2018;10:7-20.

28. Chinnala KM, Panigrahy RN, Bantu R, Sravanthi B. Formulation and evaluation of mouth dissolving films containing tizanidine hydrochloride. Int J Pharm Res Health Sci 2015;3:621-62.

29. Prabhu P, Malli R, Koland M, Vijaynarayana K, D'Souza U, Harish N, et al. Formulation and evaluation of fast dissolving films of levocitirizine dihydrochloride. Int J Pharm Investig 2011;1:99-104.

30. Manmat GS, Milind LS, Santosh PA, Disouza JI. Fast dissolving HPMC E5 based oral film for rapid absorption of metoprolol tartrate. Eur J Pharm Med Res 2014;1:75-91.

31. Doddayya H, Patil SS, Sree GR, Waseem H, Udupi RH. Design and in vitro evaluation of fast dissolving films containing HP $\beta$ $\mathrm{CD}$ inclusion complexes of lamotrigine. J Drug Delivery Ther 2014;4:99-106.

32. Sapkal NP, Kilor VA, Daud AS, Bonde MN. Development of fast dissolving oral thin films of ambroxol hydrochloride: effect of formulation variables. J Adv Pharm Res 2011;2:102-9.

33. Kaza R, Elevate PR, Ravouru N. Design, and characterization of fast dissolving films of valsartan. Turkish J Pharm Sci 2014;11:175-84.

34. Trivedi J, Patel J, Patel U. Formulation development and evaluation of fast dissolving film of cinnarizine. Int J Pharm Bio 2014;3:639-52.

35. Salman ZD, Maraie NK, Alabbassi MG, Ghareeb MM. In vitro/In vivo evaluation and bioavailability study of amitriptyline hydrochloride from the optimized oral fast dissolving films. UK J Pharm Bio 2014;2:32-42.

36. Ali MS, Vijendar C, Kumar S, Krishnaveni J. Formulation and evaluation of fast dissolving oral films of diazepam. J Pharmacovigilance 2016;4:210-5.

37. Choudhary DR, Patel VA, Chhalotiya UK, Patel HV, Kundawala AJ. Formulation and evaluation of fast dissolving film of 
levocetirizine dihydrochloride using different grades of methocel. J Pharm Res 2011;4:2919-24.

38. Abd-Alhammid SN, Saleeh HH. Formulation and evaluation of flurbiprofen oral film. Iraqi J Pharm Sci 2014;23:53-9.

39. Jadhav YG, Galgatte UC, Chaudhari PD. Challenges in formulation development of fast dissolving oral film. Indo Am J Pharm Res 2013;3:6391-407.

40. Chauhan SS, Lin S, Madan PL. Preparation and evaluation of nicotine hydrogen tartrate fast dissolving films for smoking cessation. Asian J Pharm Sci 2012;7:181-92.

41. Bala R, Sharma SH. Formulation optimization and evaluation of fast dissolvingfilm of aprepitant by using the design of the experiment. Bull Fac Pharm (Cairo Univ) 2018:1-10. https:// doi.org/10.1016/j.bfopcu.2018.04.002.
42. Jain AK, Kakde A, Jain CP, Meena MK, Gaur K. Effect of a combination of surfactant and super disintegrating agent on in vitro disintegration and dissolution release profile of medroxyprogesterone acetate tablet. Int J Pharm Clin Res 2010;2:36-9.

43. Dinge A, Nagarsenker M. Formulation, and evaluation of fast dissolving films for delivery of triclosan to the oral cavity. AAPS J 2008;9:349-56.

44. Mohanachandran PS, Sindhumol PG, Kiran TS Superdisintegrant: an overview. Int J Pharma Sci Rev Res 2011;6:105-9.

45. Khan WU. Fabrication and evaluation of fast dissolving dosage form of domperidone. Scholar Res Library 2015;7: 136-221. 